\title{
Language orientations of Chilean secondary students regarding the study of English as a foreign language ${ }^{1}$
}

\section{Orientaciones de lenguaje de estudiantes de secundaria chilenos en relación al estudio de inglés como lengua extranjera}

\author{
Mg. Corinne Barger ${ }^{2}$ \\ Dr. Pedro Sandoval Rubilar ${ }^{3}$
}

\begin{abstract}
Citation/ Para citar este Artículo: Barger, C. y Sandoval Rubilar, P. (2020). Language orientations of Chilean secondary students regarding the study of English as a foreign language. Colomb. Appl. Linguistic. J., 22(2), pp. 142-156.

Received: 14-Nov.-2019 / Accepted: 05-sep.-2020

DOI: https://doi.org/10.14483/22487085.15554
\end{abstract}

\begin{abstract}
Why teach English in Chile? Dominant public discourse claims for economic development, but with limited social mobility, do students from differing socio-economic groups perceive the same need? Recognising the influence of student belief systems on language acquisition, clashing language orientations could be creating unfavourable classroom environments. Thus, this study set out to identify the language orientations that secondary students recognise and hold in relation to the study of English with the purpose of helping English as foreign language (EFL) teachers become aware of the plurality of student perceptions. This was a qualitative multiple-case study which utilised a card-sorting technique paired with hierarchical cluster analysis and multidimensional scaling (MDS) to identify the language orientations and their constructs and semi-structured interviews and classroom observations for verification. Whilst the language orientations students recognise and hold were found to be similar across socio-economic lines, an important issue is the divergence identified between the language orientations associated with the classroom and those that represent student interests, which could be explained due to the lack of intentional and conscious dialogue about the purpose of the classroom curriculum. Vision planning is proposed as a tool for teachers to address this breach between students and classroom curriculum.
\end{abstract}

Keywords: card-sorting technique, classroom curriculum, language orientations, multidimensional scaling

\section{Resumen}

¿Por qué enseñar inglés en Chile? El discurso público dominante reclama desarrollo económico, pero con movilidad social limitada. ¿Perciben los diferentes grupos socioeconómicos la misma necesidad? Reconociendo la influencia de los sistemas de creencias estudiantiles en la adquisición de lenguaje, las orientaciones de lenguaje contradictorias podrían crear entornos de aula desfavorables. Por ello, este estudio se propuso identificar las orientaciones de lenguaje que los estudiantes de secundaria reconocen y mantienen en relación con el estudio del inglés con el propósito de ayudar a los docentes de inglés como lengua extranjera (EFL) a tomar conciencia de la pluralidad de percepciones

\footnotetext{
1 This article is a product of a master's thesis completed to obtain a master's degree in education at the Universidad del Bío Bío in Chillan, Chile.

2 Universidad del Bío Bío, Chile. ORCID (D): https://orcid.org/0000-0001-5230-7993. cbarger@ubiobio.cl

3 Universidad del Bío Bío, Chile. ORCID D: https://orcid.org/0000-0001-7503-756X. psandoval@ubiobio.cl
} 
estudiantiles. Este estudio cualitativo de caso múltiple utilizó el ordenamiento de tarjetas con análisis jerárquico y escalamiento multidimensional para identificar las orientaciones y sus construcciones, y entrevistas semiestructuradas y observaciones en aula para verificación. Mientras se encontró que las orientaciones que los estudiantes reconocen y mantienen son similares en todos los niveles socioeconómicos, un problema importante es la divergencia entre las orientaciones asociadas con el aula y las que representan el interés estudiantil, lo que podría explicarse debido a la falta de diálogo intencional sobre el propósito del currículo. Se propone la planificación de visión como una herramienta para que los docentes aborden esta brecha entre los estudiantes y el currículo.

Palabras clave: ordenamiento de tarjetas, currículo de aula, orientaciones de lenguaje, escalamiento multidimensional

\section{Introduction}

Like many countries in the world, Chile has incorporated a mandatory English as a foreign language (EFL) course into the national curriculum with the hopes to produce an English proficient population. Unfortunately, national and international standardised assessments have confirmed that the large majority of secondary students are unable to reach the goal of a B1 proficiency level as defined by the Common European Framework of Reference for Languages (Rojas et al., 2013; Tagle et al., 2014; EF Education First Ltd., 2018). In 2019, Education First Ltd. finally assessed Chile as having a medium English proficiency, but still differences emerge between regions, those with the major metropolitan cities having this new higher assessed level (EF Education First Ltd., 2019). Hence, what is holding Chile back from language proficiency? Kormos and Kiddle (2013) and Gómez and Pérez (2015) suggested that one piece of the puzzle is the lack of time and effort invested by students in the study of the language. However, with Chilean EFL teachers still using outdated methodologies (Germany $\mathcal{E}$ Cartes, 2000; McBride, 2009; Rojas et al., 2013; Harjanne et al., 2017), although after several reforms the national curriculum is now more oriented to the communicational approach (Barahona, 2016), do students find that their English classes will help them reach their personal language goals? This study explores the idea that potentially the teachers' and students' lack of conscious understanding of their language orientations and belief systems and the limited dialogue about these language goals inhibit a more effective implementation and reception of the improved curriculum reforms.

Considering the geopolitical situation of Chile as a former Spanish colony located in South America, why is English needed? The answer to this question represents the language orientations recognised, and seeing as there are a multitude of language orientations, this means that different groups will most likely have diverse perspectives about why the study of English is or is not important for the Chilean population. Without a conscious understanding of the different language orientations that exist in the classroom, it is possible that poor student motivation could be due to clashing belief systems with the teacher and/or classroom curriculum. Glas (2008) demonstrated that the dominant public discourse is heavily influenced by an instrumental language orientation that considers English as a tool for economic development for the country, but she also recognised that there is a resistance discourse. Thus, with social mobility limited to only short distances in the bottom half of the social pyramid (Espinoza et al., 2014), is it possible that the division of labour could influence the language orientations that students from different socio-economic groups hold?

Recognising the current student motivation problems and the power student belief systems about language have on the acquisition process as explained by Krashen (1982), this study set out to identify the language orientations that secondary students in Chile perceive and hold with respect to the study of EFL. Teachers' awareness of the language orientations held by their students could be an influential tool in combating demotivation and more importantly in orienting the classroom curriculum. It is for this reason that the research objectives of this study are the following:

a. to identify the language orientations that Chilean secondary students recognise in relation to the study of EFL and 
b. to understand which of those language orientations Chilean secondary students hold in relation to the study of EFL.

\section{Language Orientations and the Foreign Language Classroom}

The definition of language orientations as supported by various second language acquisition (SLA) researchers is that "orientations are longrange goals, which, along with attitudes, sustain students' motivation with an additional facet that these long-range goals break up into clusters of orientations whose definition is context-dependent' (Belmechri \& Hummel, 1998, p. 223). The concept of language orientations can be found in various fields of research, such as language planning and SLA. Within language planning, these orientations are considered the different ways society perceives the language and especially its role within society, with the orientations of language-as-problem, language-as-right and language-as-resource being three of the principal orientations studied in this field (Ruiz, 1984). Here, the language orientation takes on a more ideological role which influences the objectives and formation of language policies. Within the SLA field, language orientations are tightly related to the study of language-learning motivation being distinguished from the concept of motivation by the linkage of the orientations to a goal similar to goal theory as explained by Guilloteaux (2007). In both areas, it is recognised that language attitudes and belief systems have an influential power on the use and acquisition of language, making the study of these orientations in the EFL classroom relevant.

Returning to the definition, noting the contextdependent aspect is crucial as the language orientations that students perceive are heavily influenced by their cultural context and individual characteristics, which can be seen in the changes that the original integrative orientation proposed by Lambert and Gardner has gone through over the past decades. Whilst potentially misunderstood as an orientation, Lambert and Gardner began the study of language orientations with the creation of the 'integrativeness' concept which helped explain student motivation in Canada for learning a second language (Guilloteaux, 2007). The integrativeness looked at student motivation towards language learning due to an interest and willingness to learn about and interact in the L2 (second language) community, recognising the positive effect that this integrativeness could have on language acquisition. Notwithstanding, one of the many critiques of Lambert and Gardner's theory is based on the cultural context that their integrative orientation was formed, as not all language learners are located in bilingual contexts, such as the Canadian. Accordingly, Clément and Kruidenier theorised the sociocultural orientation which was conceptualised to fit a unicultural context along with other orientations, such as friendship, travel and knowledge (Guilloteaux, 2007). Beyond simply adapting the integrative orientation to the different cultural contexts though, other researchers have also affirmed that there were simply different language orientations that existed within the various cultural environments as with the case in Taiwan (Warden E Lin, 2000).

The cultural differences of countries are not the only context-dependent aspect that has been identified. More current SLA research has shown the importance of the ability of an individual to visualise the L2 self as explained in the L2 Motivational Self System (Dörnyei, 2005). This theory demonstrates how student goals can be defined in terms of an ideal L2 self, which represents 'a desirable selfimage of the kind of L2 user that one would ideally like to be in the future' (You et al., 2016, p.96) and an Ought-to L2 Self, which 'reflects the attributes that one believes one ought to possess to meet expectations and avoid possible negative outcomes in the process of L2 learning' (You et al., 2016, p.96).

Thus, recognising the influence of the cultural context on the orientations and linguistic goals of language learners is essential, especially with EFL to avoid the continuation of the omnipresent linguistic hegemony of English. Chile is characterised by neoliberalism, and the dominant public discourse commonly discusses urgency for the population to acquire English due to the status of the language as the global language and its ability to help ignite economic development (Glas, 2008). Nevertheless, Glas (2008) explained that this urgency to have 
an English proficient population 'gives rise to a suspicion that government policies are a form of submission to the demands of the world economic order' (p.115). Recognising that the dominant discourse has an instrumental orientation due to the neoliberalist ideology in place in Chile, it is possible that this discourse will influence the Ought-to L2 Self of the students. Csizér and Dörnyei (2005) explained "pragmatic, utilitarian expectations concerning a L2 are socially constructed and reinforced in a community through social influences' and 'are also dependent on the perceived importance of the L2' (p.27); thus, if these pragmatic instrumental perceptions of the language are propagated through social consensus and public discourse, then it will probably also influence the ought-to L2 selves of the Chilean EFL students. Nonetheless, plausibility is a relevant feature partially dictating the motivational influence of the L2 selves (Muir \& Dörnyei, 2013), and if the Chilean society is marked by limited social mobility, then will this pragmatic Ought-to L2 Self feel plausible? Thankfully, it has also been shown that the other aspects of the L2 Motivational Self System, the L2 Learning Environment and the Ideal-L2 Self have greater influence in comparison with the Ought-to L2 Self on motivated student behaviour (Dörnyei \& Chan, 2013).

\section{Methodology}

Acknowledging the importance of the contextdependency of the clustering of the language orientations, this study used the methodological design of Kono (2001) as a guide to identify the language orientations and their constructs without defining a priori the orientations to be identified. Thus, the methodology employed was a qualitative multiple-case study designed under the transcendental realism paradigm of Miles and Huberman (1994) due to their belief that 'qualitative data analysis is a continuous, iterative enterprise' (p.12). The study was designed in different phases and whose main form of data collection was a cardsorting technique paired with hierarchical cluster analysis and multidimensional scaling (MDS) and was finalised using semi-structured interviews and class observations as verification procedures. Card sorting is a technique which asks the participants to group different stimuli to understand how individuals categorise different phenomena and allows for the analysis of emergent categories, thereby being a suitable technique for the identification of language orientations without having to predetermine which orientations were going to be evaluated.

\section{Procedures}

Word Selection: Obtaining the stimuli for the creation of the cards was crucial to complete the card sorting. For this, the initial phase of the study included semi-structured interviews held with five university EFL education students who were completing or who had completed their student teaching practicum. With the descriptive coding of the interview transcripts, 33 codes which represented different beliefs, values and concepts about the teaching and learning of English were selected to be utilised in the field study card-sorting activity.

Data Collection: With the finalised list of stimuli and upon receiving authorisation by the administration and guardians of the participating students, the card-sorting activity was implemented with high school students at four different schools located in the city of Chillan, Chile. During the activity, the researcher provided each student volunteering a bag with 33 cards which represented the different stimuli previously identified and were instructed to sort the cards into diverse groups on the basis of a personally identified similarity with the only rule being that they could not sort the cards on the basis of a grammatical similarity (ex: no grouping of verbs). The students identified their different groups using the numbering of the stimuli and recorded this information on a translated and culturally-adapted version of the card-sorting instrument designed and used by Kono (2001). Once finished, the students were asked to complete a demographic questionnaire.

Data Verification: The semi-structured interviews were used with students from each of the four schools to verify the clustering and conceptual understanding of each of the language orientations identified from the card-sorting activity. In total, 16 students were interviewed from the different establishments as part of the verification process. 


\section{Participants}

As there was a belief that the socio-economic level could be connected to the diverse language orientations held, the students were selected to represent diverse socio-economic levels and were identified using the SES levels reported for the Chilean schools by the Agencia de Calidad on the national SIMCE (Sistema de Medición de la Calidad de la Educación) assessment. Thus, the research activities took place at four governmentally subsidised schools representing the middle, middlelow and low socio-economic levels. The Agencia de Calidad classifies socio-economic status on the basis of the number of years of schooling of the guardians, the reported monthly income and the percentage of the students at the school categorised as at-risk. School \#1 was a vocational-technical high school which represented a low socio-economic level with $71.1 \%$ to $100 \%$ of the students considered at-risk and with the majority of the guardians declaring a monthly salary of 340.000 clp. School \#2 being an establishment with a heavier focus on the teaching of English was classified as having a middle socioeconomic level, similar to school \#3 which did not have this additional focus on the teaching of English. The guardians of both schools reported a monthly income of 490.000 to $740.000 \mathrm{clp}$, and as institutions, the schools had between $36.01 \%$ and $54 \%$ of their students considered to be atrisk. School \#4 was classified with a low-middle socio-economic level with the guardians declaring a monthly income of 340.000 to $490.000 \mathrm{clp}$ and with $54.01 \%$ to $71 \%$ of the students deemed at-risk. Due to the need for deeper level analysis in the cardsorting activity, the participants were high school students, and in total, 283 students participated in the card-sorting activity of which $130(48.1 \%)$ were female, 136 (45.9\%) were male and 17 (6\%) did not report their gender.

\section{Data Analysis}

For the data analysis, hierarchal cluster analysis (HCA) and MDS were used with the SPSS Statistics Version 22 software. These two analysis techniques are commonly cited as being mutually complementary as they both help visualise cluster formation but with different focuses, where hierarchical cluster analysis focuses on the smaller distances between the individual codes whilst MDS focuses on the larger distances between the clusters themselves (Kruskal \& Wish, 1978, in Kono, 2001, p.103). HCA and MDS are techniques which analyse the perceived similarity that participants find between different codes as expressed through the groupings of the codes. To run both of these analysis techniques, the data collected from each school first had to be transformed into matrices using a dichotomous structure representing perceived similarity or lack thereof. After the transformation of the data, the dendrograms were produced with HCA using the average linkage, and the derived stimulus configurations were produced with MDS.

One of the benefits to using HCA is that the number of clusters was not needed a priori (Yim \& Ramdeen, 2015). This was pivotal as one of the principal aims of this study was to identify the language orientations that existed amongst the students in the cultural environment being studied; thus, the different clades identified in the dendrogram tree diagram represented the language orientations conceived by the EFL students. Whilst the number of clusters was not selected a priori, the results from a pilot study helped understand the possible number of clusters and thus calculate the minimal sample needed for a more reliable dendrogram. According to Formann (1984), the sample size should be at least $2^{\mathrm{C}}$ and preferably $5^{*} 2^{\mathrm{C}}$, where $\mathrm{C}$ represents the number of clusters (in Dolnicar, 2002), meaning that if there were five clusters as seen in the pilot study, a minimum of 32 participants were needed.

Unfortunately, HCA has its limitations: once a decision is made about the linkage between two variables, this decision thus affects the rest of the dendrogram formation, which is important to consider when reviewing the results. For the verification of the reliability of the dendrograms, random samples of each of the four data groups were analysed with the same linkage technique to confirm the cluster formation of the original samples, allowing the researcher to ensure that the behaviour of the data did not change upon removing random data points from the analysis. More importantly though, the dendrograms were also verified with the inclusion of MDS and the production of the derived stimulus configurations which are spatial maps that 
represent the cluster formation and distances (or dissimilarity) between the different clusters. For the MDS analysis and the dimension selection, the study considered the stress and the interpretability of the graphs, following Kruskal's (1964) stress criterion and recommendation for the use of the t-dimension over the $t+1$ dimension if the improved stress level does not provide any additional information about the structure.

\section{Biographical Data Analysis Results}

Before evaluating the language orientations identified by the students, a biographical analysis was completed to understand how the students' connection with English outside of the classroom was similar or different across the four different institutions. Due to the previous supposition that the socio-economic level of the students could influence their language orientations, they were surveyed about the use of English by their family and friends as well as travel experience and interaction with native speakers. The results are summarised below in Table 1, where it is seen that higher socioeconomic levels represented by schools \#2 and \#3 do have a slightly greater connection with the language, especially in terms of travel opportunities and with friends who speak English. However, rather than seeing important differences due to socioeconomic levels, there seem to be differences based on the type of school, as school \#2 which is a school with a special curricular emphasis on the teaching of English shows across the different variables higher connections with the language and which could explain the differences seen in the variables about contact with native speakers and the personal use of the language with friends or family. This could demonstrate that whilst socio-economic levels might have some explanatory power, the school curriculum could also be just as important in defining student connection with foreign languages such as English for the Chilean student body.

In addition to personal connection with the language, student satisfaction with their English classes and the language itself were also evaluated as seen in Table 1. The students responded using a Likert scale from 1 to 5 , with 5 representing high levels of satisfaction. Again, the socio-economic level for the cases studied does not seem to be an explanatory factor for the statistically significant differences between the means for each of the variables. Furthermore, the students generally reported an overall satisfaction with the language and the class but with a slightly higher interest for the language in comparison with the English classes.

\section{Language Orientation Identification Results with HCA and MDS Analysis}

HCA was performed using the average linkage technique for each of the four data samples. Careful interpretation of the dendrograms produced in collaboration with the student interviews led to the

Table 1. Student Satisfaction with the English Language and English Class.

\begin{tabular}{lcccccccc}
\hline & \multicolumn{2}{c}{ School 1 } & \multicolumn{2}{c}{ School 2 } & & School 3 & School 4 \\
\cline { 2 - 7 } & Mean & $\begin{array}{c}\text { Standard } \\
\text { deviation }\end{array}$ & Mean & $\begin{array}{c}\text { Standard } \\
\text { deviation }\end{array}$ & Mean & $\begin{array}{c}\text { Standard } \\
\text { deviation }\end{array}$ & Mean & $\begin{array}{c}\text { Standard } \\
\text { deviation }\end{array}$ \\
\hline $\begin{array}{l}\text { Satisfaction with } \\
\text { language }\end{array}$ & $3.55 \mathrm{a}$ & 1.07 & $4.39 \mathrm{~b}$ & 0.83 & $3.93 \mathrm{a}, \mathrm{b}$ & 0.86 & $4.04 \mathrm{~b}$ & 0.96 \\
\hline $\begin{array}{l}\text { Satisfaction with } \\
\text { class }\end{array}$ & $3.47 \mathrm{a}$ & 1.22 & $3.92 \mathrm{~b}$ & 0.98 & $3.1 \mathrm{a}$ & 1.06 & $4.02 \mathrm{~b}$ & 1.1
\end{tabular}

Note: Values in the same row and subtable not sharing the same subscript are significantly different $\mathrm{p}<.05$ in the two-sided test of equality for common means. Cells with no subscript are not included in the test. Tests assume equal variances.

1. Tests are adjusted for all pairwise comparisons within a row of each innermost subtable using the Bonferroni correction. 
selection of a five-cluster model in each of the data sets which can be seen in the Appendix. Beyond just having the same number of identified clusters, variable membership for each of the clusters was extremely similar with only minor differences in the clusters. The student descriptions of each of the clusters at each of the schools were helpful in clarifying the cluster similarity in terms of variable membership and meaning. Thus, the results from the cluster analysis provide no significant evidence that the socio-economic level influences the language orientations that the students studied recognise.

As previously explained, the MDS analysis was used as a complementary analysis to verify the results of the dendrograms from the HCA. Little difference was seen between the clustering in the dendrograms and the MDS configurations. Following Kruskal's (1964) criterion explaining that $0 \%$ is optimal, $2.5 \%$ excellent, $5 \%$ good, $10 \%$ reasonable and $20 \%$ poor, the configurations for the four schools demonstrate a reasonable stress level considering four dimension configurations, namely, school 1 with a stress of 0.104 , school 2 with 0.082 , school 3 with 0.128 and school 4 with 0.136 . Nevertheless, in the case of school \#3, a threedimensional model was used as the additional 4th dimension did not provide any additional insight to the clustering of the stimuli. The higher stress levels in schools \#3 and \#4 could be accounted for due to the smaller sample size available. As seen in the four configurations below, five clusters continue to be the tendency, except for school \#4, where only four clusters were identified.

\section{Interpretation of Language Orientations}

This study aimed to identify the language orientations that the EFL students in Chile conceptualise and identify with, with the hope to help educators better understand the student motivations and perceptions towards the study of English in Chile. Although the cluster analysis led to the selection of five-cluster models, through the student interviews, six different language

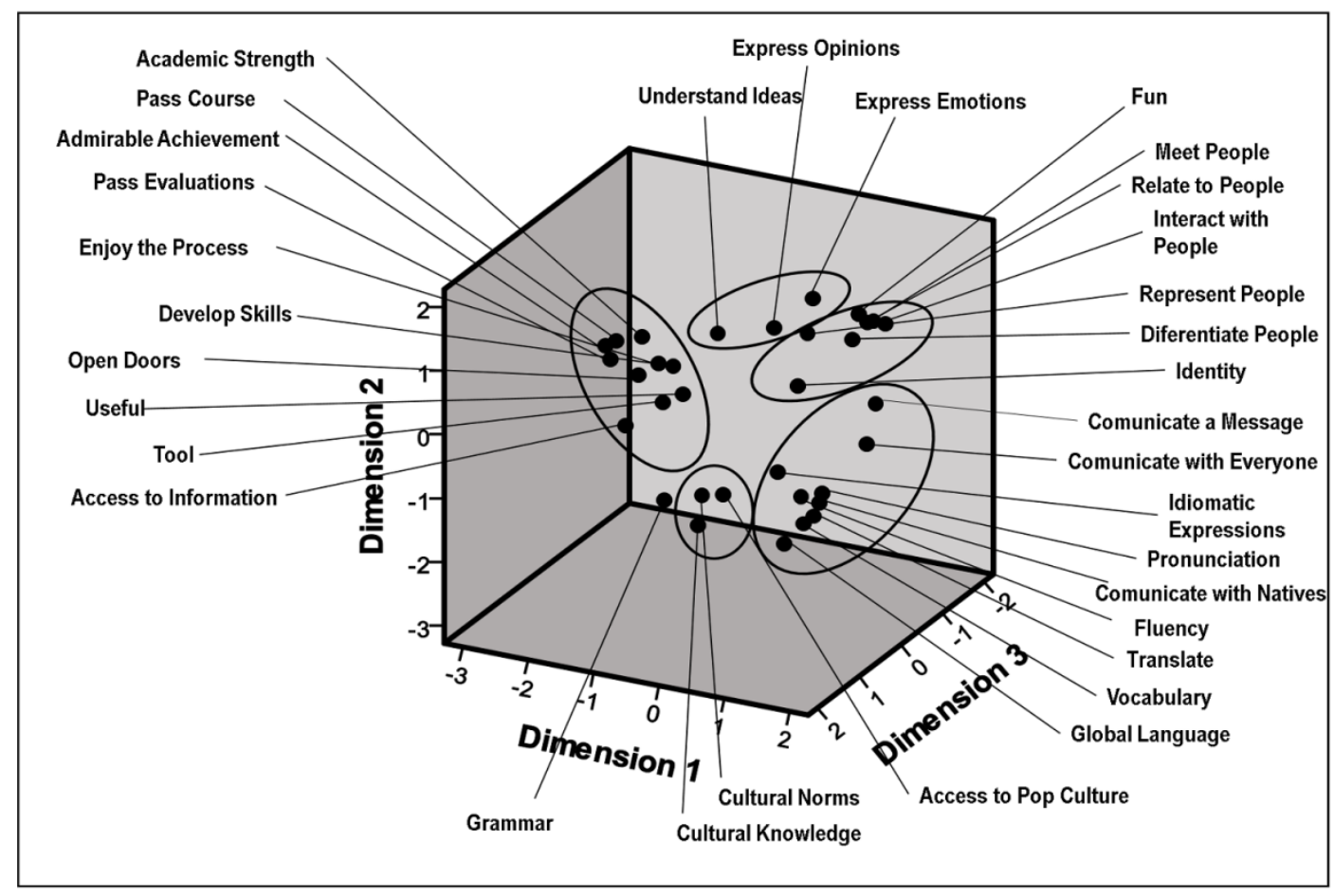

Figure 1. Four-Dimension MDS Configuration for School 1. 


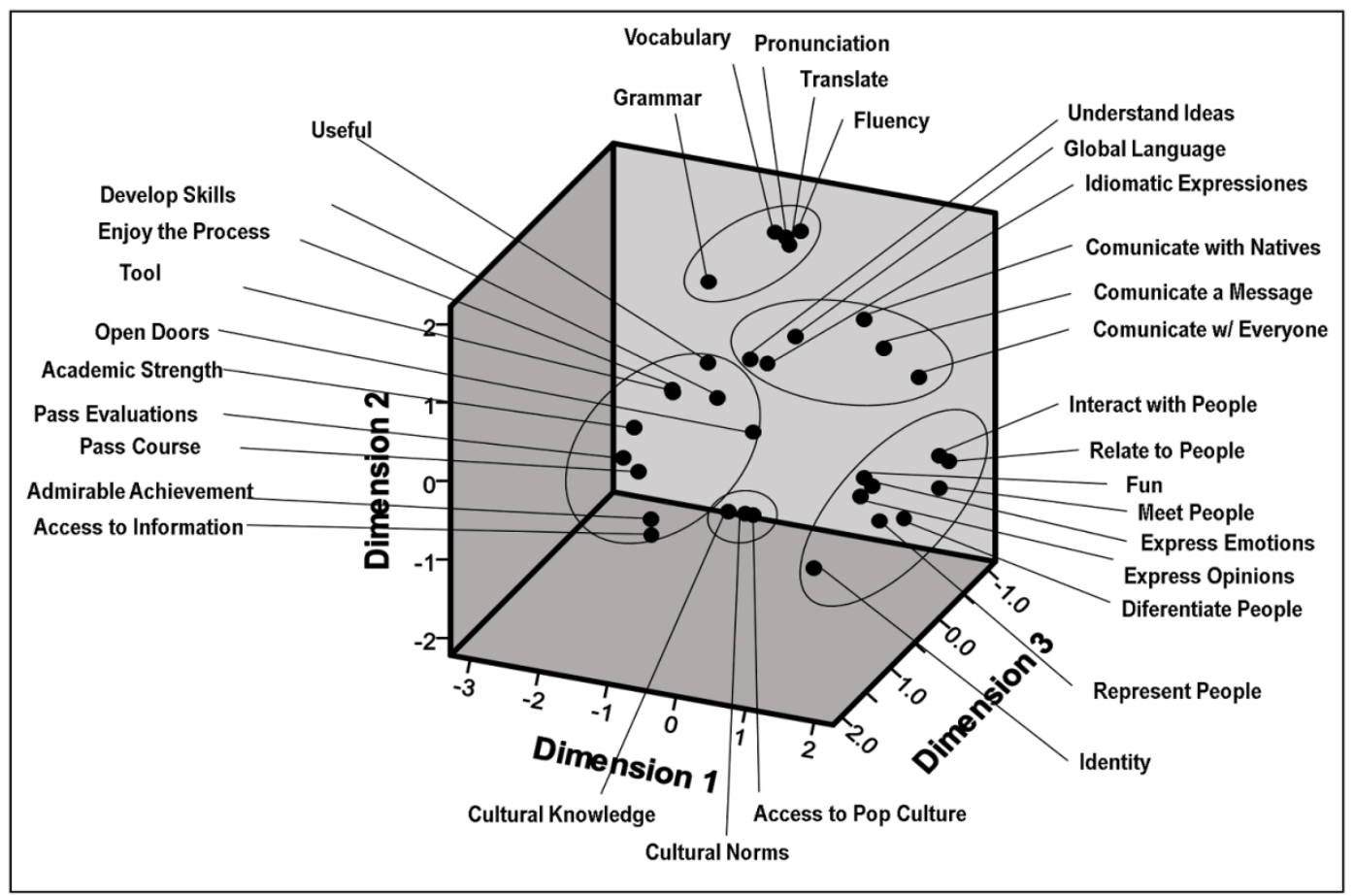

Figure 2. Four-Dimension MDS Configuration for School 2.

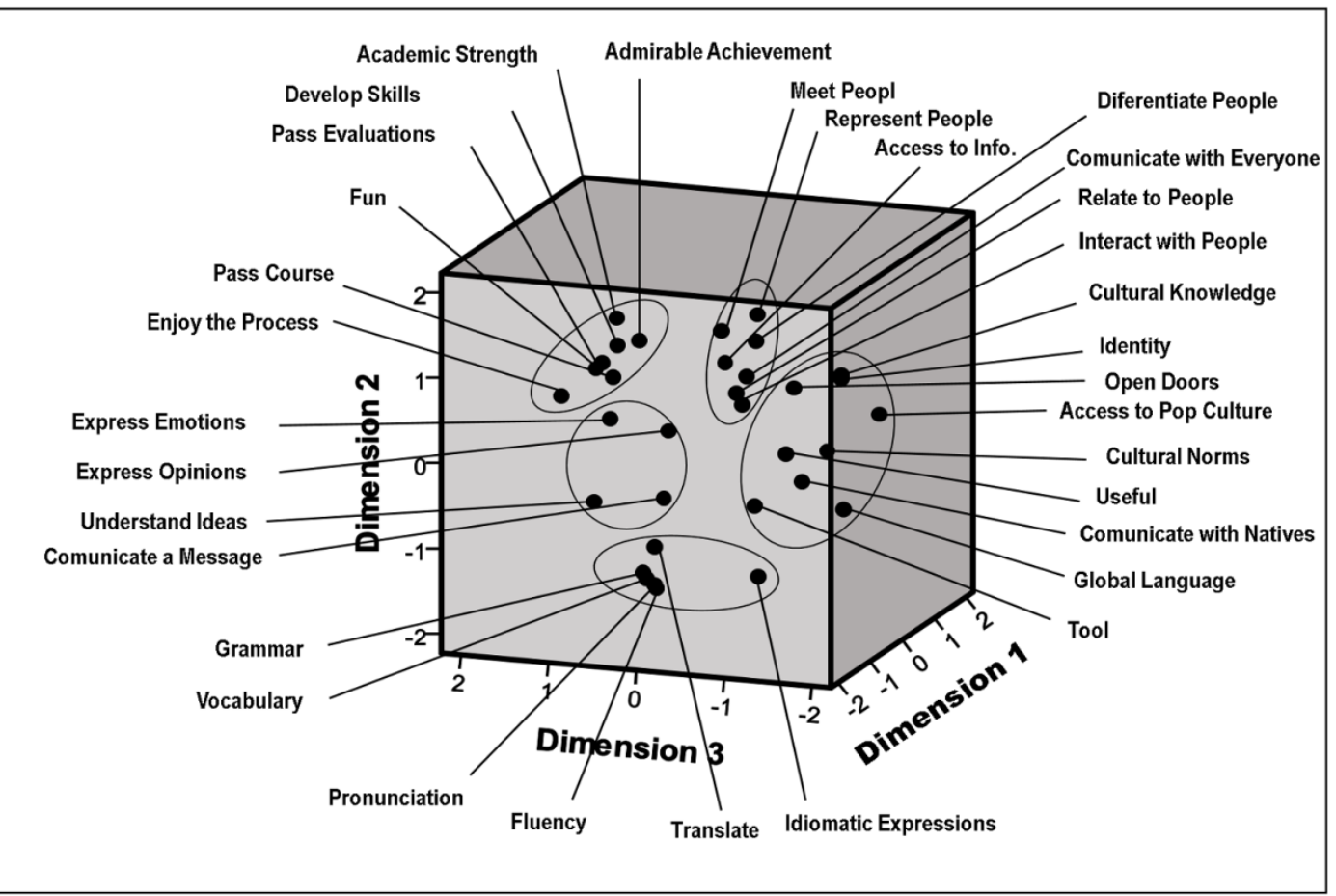

Figure 3. Three-Dimension MDS Configuration for School 3. 


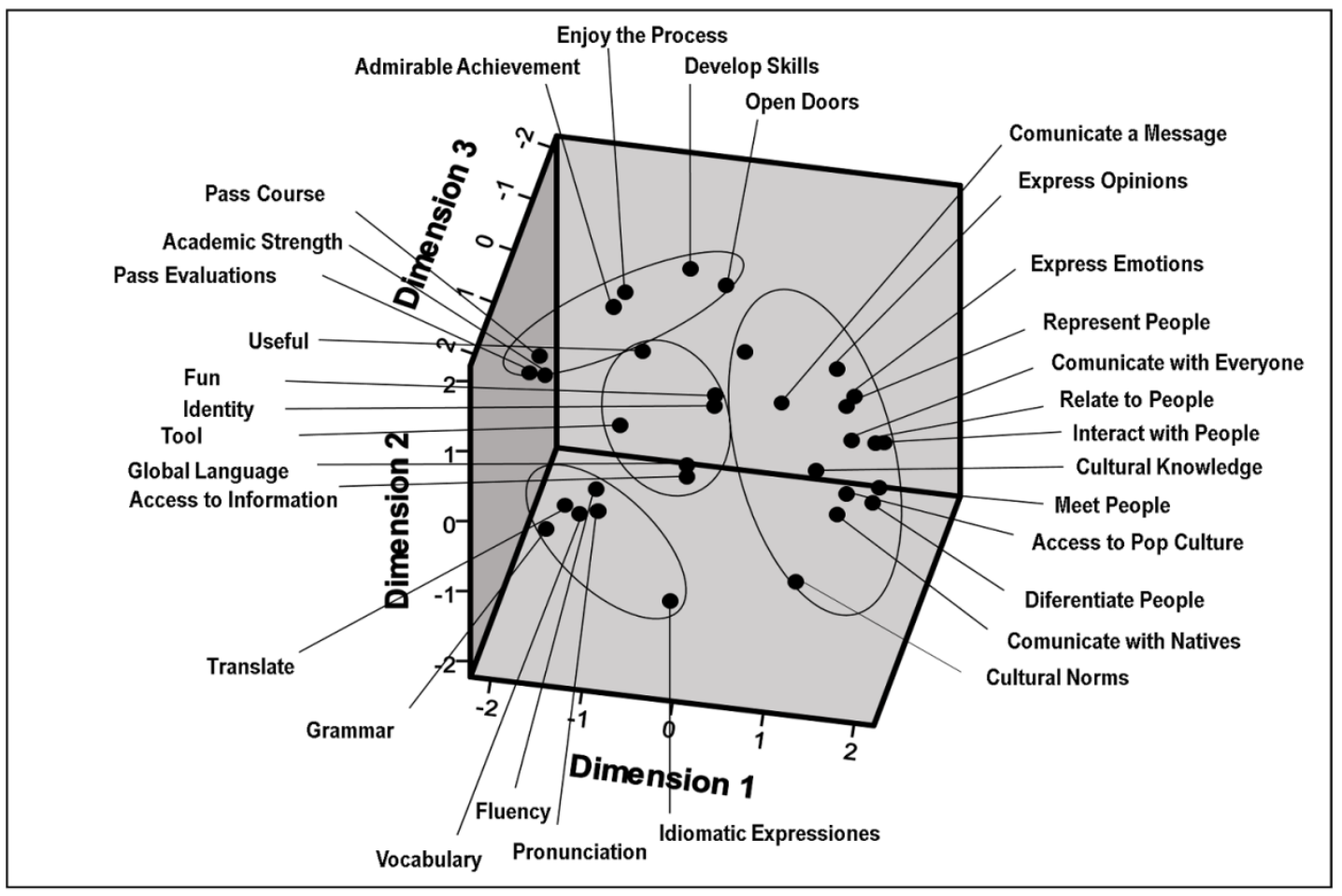

Figure 4. Four-Dimension MDS Configuration for School 4.

orientations were identified. Moreover, it was with the student interviews where it was made clear that these orientations were also divided into two larger categories: one group of orientations that students relate more to what currently takes place in the EFL classroom and the other group seems to more closely represent the motivations of the students towards wanting to acquire the English language. This larger division between the language orientations should be taken as a concern because it demonstrates a perceived separation of what occurs in the classroom and the actual motivators for the Chilean students studied across socio-economic levels. Originally, there was a supposition that the language orientations of the students would be influenced by the socio-economic level; however, there were no significant differences seen in the present study between the language orientations conceived by the students in the HCA and MDS analysis nor between the language orientations identified as being connected to personal use or the classroom.
The language orientations identified that were more frequently related to the EFL classroom were the belief that (1) English is a school subject, (2) English is a tool which can be leveraged and (3) the perception that English is a set of structures (grammatical, semantical and phonological). In addition, the language orientations more frequently related to outside of the classroom were the perspectives that English can be a means of communication, a means of social interaction and the recognition of English having a cultural connection. These six orientations are briefly described below on the basis of the cluster analysis and the student interviews.

English as a Subject. Similar to other EFL contexts (Warden E Lin, 2000), one of the identified language orientations conceptualised English as a mere subject that makes up part of the mandatory national curriculum. Here, the concept of obligation was mentioned by the students from the different schools, but interestingly, there was no 
personal sensation of obligation expressed, only an acknowledged feeling of obligation in their peers. This can be seen in the following student statement which demonstrates the peer recognised obligation and the recognition of student satisfaction with academic achievement:

'...obviamente como están como desesperados aprendiendo inglés a la fuerza para poder tener azul...' [obviously since they are desperately studying English by force to be able to have a passing grade] (student 3, school 3).

'hay algunos que estudian mucho, después les va bien, y eso de verdad que como que sienten algo, su recompensa' [there are some that study a lot, afterwards they do well, and truly they feel something, the compensation] (student 3, school 3).

English as a Tool. This orientation sees English as a global language that would prove to be useful in future professional, academic and self-realisation contexts. The major emphasis was placed on the benefits that the language could bring a student and relates well with the instrumental orientation identified in the discourse of the Chilean media (Glas, 2008). However, it was also tightly connected to the previous orientation in many of the dendrograms. Additionally, in the student responses, there seemed to be a lack of clarity at times about the specific role the language and formal coursework play in obtaining the commonly referenced professional benefits, thereby leading to the description of six orientations rather than only the five identified through the cluster analysis.

Mechanical English. This orientation had the most uniform structure across the four different participating establishments. It conceptualised English as a set of structures recognising that as a language, English is composed of grammar structures, vocabulary and phonetics which should be studied and learned to be able to use the language. Many of the students when discussing this orientation often referred to these structures as the content of their English courses in the schools, which could also be a manifestation of the emphasis on the more traditional grammar translation method rather than a communicative approach which has been noted by many researchers in the classroom (Germany \& Cartes, 2000; McBride, 2009; Rojas et al., 2013) and in the teacher methodology course at the university (Martin, 2016). This can be seen in the student response explaining the following:

'si sumo todo aprendo el inglés...es que si tengo eso prácticamente sabría inglés' [if I sum up everything I learn English...that is if I have this I practically know English] (student 2, school 3).

This demonstrates the student's limited view of language as a set of structures, an understanding that the comprehension of grammar structures, vocabulary and pronunciation leads to a complete knowledge of English.

English as a Means of Communication. Similar to the descriptive language orientation described by Kono (2001), the students defined this orientation as one that sees English as a means to be able to communicate with others but with a focus on the expression and comprehension of the communication. This cluster was commonly formed by phrases related to the expression of messages, ideas and emotions as seen in the following student response:

'...sería como un inglés comunicacional, más enfocado a como uno puede expresarse, o de decir cierta palabra con cierto tono de voz, con todo eso, como uno puede entender a la otra persona también, y en el fondo, entenderse, comunicarse, entender el inglés de la otra persona y que esa persona también te entienda el inglés tuyo' [...it would be like a conversational English, more focused on how someone can express themselves or can say a certain word with a certain tone of voice, with all this, how someone can also understand another person, and in the end, be understood, communicate understand the English of another person and that this person also understands your English] (student 3, school 3)

English as a Means of Social Interaction. Whilst the previous orientation was focused on the use of the language to communicate ideas and messages, this orientation focuses on the ability of the language 
to connect individuals. The students explained that English could be a means to socialise with others around the world, allowing them to increase their network of friends. As Chile is a country that uses English more as a foreign language rather than a second language, this recognition of English as a means of social interaction becomes more comprehensible with the students' declaration of having English-speaking friends through the Internet, again a tendency that was seen across socio-economic groups. Below is a representative student response highlighting the following:

\begin{abstract}
'...cuando uno sabe otro idioma puede hablar con muchas más personas y puede conocer aún más personas, hay más posibilidades de hacer cosas nuevas y de divertirse, de relacionarse con más personas' [... when you know another language, you can talk with many more people and can meet even more people; there are more possibilities to do new things and to have fun, to interact with more people] (student 1, school 1)
\end{abstract}

English as a Cultural Aspect. Through the cluster analysis, it was recognised that the students understand that English is connected to culture. Notwithstanding, the depth of the understanding of this perspective was extremely superficial and could be a sign of a weakness in the teaching and learning of cultural objectives. Part of this limited understanding is due to the students' lack of understanding that language itself can be a cultural act, as much of the explanations given in the interviews recognised that the language is connected to certain cultural groups who have their own customs and traditions none of those mentioned relating to the use of language, as seen in the following student response:

"'Yo creo que cuando se aprende inglés se puede aprender otra cultura de otros países, ya que sabemos lo que están diciendo, como por ejemplo nos pueden decir que se hace tal cosa allá, y podemos descubrir que aquí no se hace y allá si' [I believe that when you learn English, you can learn other cultures from other countries, since we know what they are saying, like for example they can tell us that they do certain things, and we can discover that here we don't do that and there they do] (student 2, school 1)
This lack of understanding of language being a cultural phenomenon is especially worrisome if the students express that their ideal goals for the language is to interact with others around the globe, as they will not have the intercultural communication skills to handle those situations. In addition, if the classrooms continue to be focused on the teaching of the content identified in the mechanical English orientation, then this lack of intercultural communication skills will continue to lag, thereby limiting the future abilities of the Chilean students to benefit from the use of the language.

\section{Language Orientations and Context Associations}

To understand how the students visualised the use of the orientations within their daily lives using the card-sorting instrument, they were asked to associate three variables with their languagelearning experience in the classroom and three variables to their use of language with family and/ or friends. Using the results for the HCA and MDS analysis, the variables associated in this task were assigned to one of the six identified clusters to see which language orientations were most frequently associated with the two different contexts. Tables 2 and 3 present the frequency with which the cluster membership variables were associated with each of the two contexts (inside and outside the classroom).

Table 2 shows the language orientations that were associated with the EFL classroom, where it is seen that across the four schools, the most commonly associated orientations were English as a subject, Mechanical English and English as a tool. When compared with Table 3, it is seen that the students more frequently associated the orientations related to communication and interaction with the outside of the classroom. The reason why this distinction is highly important was seen in the student interviews, where the students from the four different establishments explained how their interests and motivations to study English stem more from the desire to communicate and interact with others. Thus, it would seem logical to think that if teachers want to ensure student motivation in the EFL classroom, this stark division between those orientations perceived to be used in the classroom 
Language orientations of Chilean secondary students regarding the study of English as a foreign language

Table 2. Language Orientations Associated with the EFL Classroom.

\begin{tabular}{|l|l|l|l|l|l|l|l|l|}
\hline \multirow{2}{*}{ Language orientations } & \multicolumn{2}{ll}{ School 1} & \multicolumn{2}{ll}{ School 2 } & \multicolumn{2}{ll}{ School 3 } & \multicolumn{2}{l|}{ School 4 } \\
\cline { 2 - 12 } & Count & $\%$ & Count & $\%$ & Count & $\%$ & Count & $\%$ \\
\hline English as a subject & 41 & 26.3 & 78 & 38.6 & 25 & 32.5 & 50 & 31.4 \\
\hline Mechanical English & 67 & 42.9 & 96 & 47.5 & 17 & 22.1 & 33 & 20.8 \\
\hline English as a tool & 16 & 10.3 & 0 & 0.0 & 20 & 25.9 & 22 & 13.8 \\
\hline English as means of communication & 3 & 1.9 & 10 & 5.0 & 4 & 5.2 & 23 & 14.5 \\
\hline English as means of interaction & 18 & 11.5 & 12 & 5.9 & 6 & 7.8 & 25 & 15.7 \\
\hline Cultural orientation & 11 & 7.1 & 6 & 3.0 & 5 & 6.5 & 6 & 3.8 \\
\hline Total & 156 & 100.0 & 202 & 100.0 & 77 & 100.0 & 159 & 100.0 \\
\hline
\end{tabular}

Table 3. Language Orientations Associated with Language Use with Friends and/or Family.

\begin{tabular}{|c|c|c|c|c|c|c|c|c|}
\hline \multirow{2}{*}{ Language orientations } & \multicolumn{2}{|c|}{ School 1} & \multicolumn{2}{|c|}{ School 2} & \multicolumn{2}{|c|}{ School 3} & \multicolumn{2}{|c|}{ School 4} \\
\hline & Count & $\%$ & Count & $\%$ & Count & $\%$ & Count & $\%$ \\
\hline English as a subject & 7 & 4.5 & 5 & 2.5 & 14 & 18.1 & 9 & 5.7 \\
\hline Mechanical English & 30 & 19.2 & 24 & 11.9 & 13 & 16.9 & 18 & 11.3 \\
\hline English as a tool & 5 & 3.2 & 0 & 0.0 & 0 & 0.0 & 36 & 22.6 \\
\hline $\begin{array}{l}\text { English as means of } \\
\text { communication }\end{array}$ & 50 & 32.05 & 108 & 53.4 & 34 & 44.2 & 60 & 37.7 \\
\hline English as means of interaction & 62 & 39.7 & 59 & 29.2 & 13 & 16.9 & 31 & 19.5 \\
\hline Cultural orientation & 2 & 1.2 & 6 & 3.0 & 3 & 3.9 & 5 & 3.1 \\
\hline Total & 156 & 100.0 & 202 & 100.0 & 77 & 100.0 & 159 & 100.0 \\
\hline
\end{tabular}

and those orientations that reflect student interest must be eliminated.

The question that follows then is about the origin of the perception of the students about the language orientations used in the classroom. Through classroom observations, several phenomena were observed which could be leading the students to perceive differences between their personal language orientations and those perceived of the classroom. The phenomenon observed and which will be explained in the following paragraphs was the unintentional dialogue about the language orientations, the lack of explanation about the learning objectives and focus on language content rather than communication.

Lack of Consciousness about Language Orientations Employed. In the eight different classes observed, there was almost no evidence of deliberate dialogue between the students and the teachers about the purpose of the activities planned and executed in the class. Ergo, the student perceptions of the language orientations of the English classroom were intuitively formed as the large majority of the teacher discourse was characterised by behaviour correction and content instruction with a noticeable absence of the reason for the learning objectives and content. The lack of intentional dialogue between the students and the teachers was also identified in the student interviews when asked about the reasons why their teachers wanted them to learn English, where the students frequently demonstrated a limited understanding of the teachers' language orientation as seen in the following response:

\footnotetext{
'Aparte de porque tiene que trabajar; o aparte de porque es su trabajo; Yo creo porque a ella le gusto aprender inglés porque le gusta aprender idiomas' [A part from because she has to work, or because it is her job, I think because she likes to learn English because she likes to learn languages] (student 2, school 1)
} 
Lack of Discussion about Learning Objectives. As observed in the classroom observations, the learning objectives continue to be mostly absent from the class. Whilst the majority of the students heard or received in writing the learning objectives, none of the observed students received an explanation of the stated objective or why this objective was important to achieve. The explanation of the learning objective is understood to be essential for students so that they have a clear understanding of the goal they are working towards during the class and have a clear comprehension of how the day's goal fits into a large scope.

Focus on 'Academic' Orientations. Similar to the perceptions of the students, much of the activities and selected content centred around those variables belonging to the orientations that consider English as a subject and English as a set of structures. This was seen in frequent grammar and vocabulary acquisition activities that were also not contextualised to oral or written communication. Comprehension of grammar structures and vocabulary is important for communicating and understanding messages, but the activities observed did not focus on using the grammar structures nor vocabulary for this purpose. An example is a vocabulary activity that asked the students to recall a list of memorised vocabulary words, and upon completion, neither the teachers nor the students incorporated these individual words in their speech again, reinforcing the idea for the students that the purpose of the class is on learning the provided content but not necessarily utilising this content to communicate and interact with others.

\section{Conclusions}

This study aimed to identify those language orientations that students recognise and identify with in relation to the study of English in an EFL context like Chile. The cluster and multidimensional analysis led to the identification of six language orientations, and the student interviews and card sorting helped in understanding that these orientations were divided into two groups. The first group was represented by those orientations more closely associated with the EFL classroom, and the second group was represented by those associated with the language use outside the classroom.
This division of language orientations is considered problematic, as previous studies have identified issues with student motivation and autonomous study. However, whilst previous studies have posited these behaviours to be products of negative attitudes that students hold about the EFL classroom (Gómez \& Pérez, 2015), it might be due to the clashing language orientations that students hold and perceive from the classroom itself. In this study, the students across the socioeconomic levels demonstrated interests for the language as seen with the high level of satisfaction indicated. Nonetheless, they also associated their school English classes more heavily with being a mandatory subject and the instrumental discourse about the language. They also recognised that the contents for these EFL classes are the grammar structures, lexical items and phonetics. Conversely, their personal interests with the language stem from their aspiration to use the language as a means to communicate and socialise with others, creating a disjunction between the perceived language orientations of the EFL classroom and the students' own personal language orientations.

This divergence could be evidence of the differing Ought-to L2 Selves and Ideal L2 Selves and could also be a product of the lack of intentional dialogue between the EFL students and the teachers about the purpose for the learning objectives and planned activities. Glas (2008) demonstrated that the common public discourse that is blatantly used throughout the Chilean media is that English is an international and instrumental language, but just because it is the most readily employed language orientation does not mean that it fits the personal perceptions and goals of the Chilean students. Instead, this means that there is a high probability that if teachers are not assertive in recognising and discussing the plurality of language orientations that exist, then students will most probably continue to associate the classroom intuitively with the dominant discourse and with the perception of English being a mandatory subject due to its inclusion in the national curriculum.

Gómez and Pérez (2015) suggested that teachers should plan meaningful communicational activities outside of the classroom in response to the negative 
attitudes they identified, but whilst important, this paper posits that the first steps EFL teachers in Chile need to take is becoming conscious of their language orientations and then incorporating more intentional dialogue about language beliefs and goals and their connection with learning objectives within the classroom. Students must recognise that what they are doing is relevant to their short- and long-term goals, especially because action planning and goal planning have already been found to be fundamental for building long-term motivated behaviour (Muir \& Dörnyei, 2013). However, this study observed that little dialogue occurs in the classroom about the learning objectives, and the dialogue about the language itself is generally in terms of the evaluations and content.

Hence, the route to beginning an intentional conversation with students about language orientations should begin with more deliberate explanation of the learning objectives, thereby helping students recognise how these objectives fit with their own language goals. However, vision planning would most likely lead to deeper conversations and classroom engagement as visualisation tasks have already seen success in further investing students in their language learning (Magid \& Chan, 2012; Munezane, 2015). The proposed solution is that teachers co-construct a vision with their students at the beginning of the year that engages the Ideal L2 Selves of the students and help them recognise how the year's objectives will help them achieve this co-constructed vision. With a vision established, the explanations of the learning objectives, the activities planned and the general teacher discourse can all be oriented around this shared sensory experience and can serve as a constant reminder of the steps being taken to achieve the vivid language goal.

From the results of this survey, it is known that students generally are interested in communicating and socialising through the language, thereby giving teachers insight into what type of visions students might have for themselves. At the same time, recognising these interests also suggests a need for a more communicational approach in terms of methodology rather than the traditional grammar focus. In sum, a shared vision could be a useful tool to make teachers and students conscious about the language orientations that exist, ensure that the conversation about these orientations is intentional and occurs throughout the school year and push teachers to incorporate activities on the basis of the communicational approach.

\section{References}

Abrahams, M. J., \& Farías, M. (2010). Struggling for change in Chilean EFL teacher education. Colombian Applied Linguistics Journal, 12(2), 110-118. https:// revistas.udistrital.edu.co/index.php/calj/article/view/87

Barahona, M. (2016). Challenges and accomplishments of ELT at primary level in Chile: Towards the aspiration of becoming a bilingual country. Education Policy Analysis Archives, 24(82). http://dx.doi. org/10.14507/epaa.24.2448

Dolnicar, S. (2002). A review of unquestioned standards in using cluster analysis for data-driven market segmentation. Faculty of Commerce-Papers, 273. https://ro.uow.edu.au/commpapers/273/

Dörnyei, Z. (2005). The psychology of the language learner: Individual differences in second language acquisition. Mahwah, NJ: Erlbaum

Dörnyei, Z., E Chan, L. (2013). Motivation and vision: An analysis of future L2 self images, sensory styles, and imagery capacity across two target languages. Language Learning, 63(3), 437-462. https://www. zoltandornyei.co.uk/journal-articles

EF Education First Ltd. (2019). EF EPI Chile. https://www. ef.com/cl/epi/regions/latin-america/chile/

EF Education First Ltd. (2018). EF English Proficiency Index (8th ed.). https://www.ef.com/ / /media/ centralefcom/epi/downloads/full-reports/v8/ef-epi2018-spanish-latam.pdf

Espinoza, V., Barozet, E., \& Méndez, M. L. (2013). Estratificación y movilidad social bajo un modelo neoliberal: El caso de Chile. Lauboratorio, 25. https://publicaciones.sociales.uba.ar/index.php/ lavboratorio/article/view/125

Germany, G. P., \& Cartes, E. N. (2000). Léxico disponible en ingléscomosegundalenguaeninstrucciónformalizada. Estudios Pedagógicos (Valdivia), 26(26), 39-50. https://scielo.conicyt.cl/scielo.php?script $=$ sci arttextEpid =S0718-07052000000100003

Glas, K. (2008). El inglés abre puertas...a que? Análisis del discurso sobre la enseñanza del inglés en Chile, 2003-2006. Revista Educación y Pedagogía 20(51), 112-122. https://dialnet.unirioja.es/servlet/ articulo?codigo $=3074263$ 
Gómez, E., \& Pérez, S. (2015). Chilean 12 ${ }^{\text {th }}$ graders' attitudes towards English as a foreign language. Colombian Applied Linguistics Journal, 17(2), 313-324. https://doi.org/10.14483/udistrital.jour. calj.2015.2.a10

Guilloteaux, M. J. (2007). Motivating language learners: A classroom-orientated investigation of teachers' motivational practices and students' motivation [Doctoral dissertation, University of Nottingham]. http://eprints.nottingham.ac.uk/10271/1/ Guilloteaux PhD.pdf

Harjanne, P., Larenas, C. D., \& Tella, S. (2017). Foreignlanguage teaching and studying in Chilean and Finnish classrooms as seen by teachers. Journal of Language and Cultural Education, 5(3), 1-21. https://doi.org/10.1515/jolace-2017-0025

Kono, N. (2001). Language orientations: Case study of a Japanese-as-a-foreign language classroom. [Dissertation for Ph.D]. Second Language Acquisition and Teaching, University of Arizona, Tucson: AZ. https://repository.arizona.edu/handle/10150/280530

Kormos, J., \& Kiddle, T. (2013). The role of socioeconomic factors in motivation to learn English as a foreign language: The case of Chile. System, 41(2), 399-412. https://eprints.lancs.ac.uk/id/ eprint/63008/1/chilesocioeconomicfactors.pdf

Kruskal, J. B. (1964). Multidimensional scaling by optimizing goodness of fit to a nonmetric hypothesis. Psychometrika, 29(1), 1-27.

Magid, M., \& Chan, L. (2012). Motivating English learners by helping them visualize their ideal L2 self: Lessons from two motivational programmes. Innovation in Language Learning and Teaching, 6, 113-125.

Martin, A. (2016). The EFL methodology course in Chile: SLTE in the expanding circle. Colombian Applied Linguistics Journal, 18(1), 24-42. https://doi. org/10.14483/calj.v18n1.9471

Miles, M. B., \& Huberman, A. M. (1994). Qualitative data analysis: An expanded sourcebook. SAGE.
Muir, C., \& Dörnyei, Z. (2013). Directed motivational currents: Using vision to create effective motivational pathways. Studies in Second Language Learning and Teaching, 3(3), 357-375. https://www.zoltandornyei. co.uk/journal-articles

Munezane, Y. (2015). Enhancing willingness to communicate: Relative effects of visualization and goal setting. The Modern Language Journal, 99(1), 175-191. https://onlinelibrary.wiley.com/doi/ abs/10.1111/modl.12193

Tagle, T, Díaz, C, Alarcón, P., Quintana, M., E Ramos, L. (2014). Creencias sobre el aprendizaje del inglés en la formación inicial docente. Educere, 18(61), 473482. https://www.redalyc.org/pdf/356/35639776009. pdf

Rojas, D., Zapata, Á., E Herrada, M. (2014). Enseñanza del Inglés en los Colegios Municipales de Chile. ¿Dónde Estamos y Hacia Dónde Vamos? Foro Educacional, (22), 95-108. http://ediciones.ucsh.cl/ojs/index.php/ ForoEducacional/article/view/668

Ruiz, R. (1984). Orientations in language planning. $N A B E$ Journal, 8(2), 15-34. https://www.tandfonline.com/ doi/abs/10.1080/08855072.1984.10668464

Warden, C. A., E Lin, H. J. (2000). Existence of integrative motivation in an Asian EFL setting. Foreign Language Annals, 33(5), 535-545. http://cwarden.org/warden/ personalPage/papers/FLA 00.pdf

Yim, O., E Ramdeen, K. T. (2015). Hierarchical cluster analysis: Comparison of three linkage measures and application to psychological data. The Quantitative Methods for Psychology, 11(1), 8-21. http://www. tqmp.org/RegularArticles/vol11-1/p008/p008.pdf

You, C. J., Dörnyei, Z., \& Csizér, K. (2016). Motivation, vision, and gender: A survey of learners of English in China. Language Learning, 66(1), 94-123. https:// www.zoltandornyei.co.uk/journal-articles 